\title{
Remarkable desmid species from the southern Patagonian highlands
}

\author{
Peter F.M. Coesel ${ }^{1 *}$, Sol PorCeL ${ }^{2}$, Alfred VAn Geest ${ }^{3} \&$ Irina Izaguirre $^{2}$
}

\author{
${ }^{1}$ Institute for Biodiversity and Ecosystem Dynamics, Faculty of Science, University of Amsterdam, Kruislaan \\ 904, NL-1098 SM Amsterdam, The Netherlands; *Corresponding author: e-mail:p.f.m.coesel@uva.nl \\ ${ }^{2}$ Departamento de Ecología, Genética y Evolución, IEGEBA (UBA-CONICET). Facultad de Ciencias Exactas \\ y Naturales, Universidad de Buenos aires, Buenos Aires, Argentina. \\ ${ }^{3}$ De Wittenkade 156, NL-1051 AN Amsterdam, The Netherlands
}

\begin{abstract}
Phytoplankton research in a number of shallow lakes in southern Patagonia revealed the occurrence of three noteworthy Cosmarium species. One of them, Cosmarium decussare BrooK et Williamson, found only once before in Antarctica, is remarkable for its highly asymmetric cell morphology. The other two species, Cosmarium chapuense and Cosmarium mickeyoides, striking by an unusual cell shape, are described as new to science. Ecological and biogeographical characteristics are discussed.
\end{abstract}

Key words: desmids, Cosmarium, Patagonian Plateau, Lake Chapu, Argentina

\section{INTRODUCTION}

Within the framework of a project on plankton diversity of lakes in Austral Patagonia a series of lakes located in the basaltic Patagonian Plateau are being sampled since 2007. Patagonia is one of the main lacustrine regions of South America where lakes are situated in two geographically different limnological zones, 'Andean Patagonia' and 'Patagonian Plateau'. The first one mostly includes deep oligotrophic lakes of glacial origin, whereas the second one hosts different types of water bodies distributed in the arid Patagonian steppe, many of them located on the basaltic plateaux. The main environmental characteristics of these two zones were detailed in previous papers (e.g., TeLL et al. 2011; IzaguirRe \& SAAD 2014). Due to remoteness of the study sites, lakes located in the Patagonian Plateau have been less investigated than those in the Andean region. Current studies by the hydrobiology research group of the University of Buenos Aires are focused on the biodiversity and ecology of planktonic food webs from two basaltic plateaux in Santa Cruz Province (Argentina): 'Strobel Lake Plateau' and 'Buenos Aires Lake Plateau'. The shallow lakes in this area are very important from the point of view of conservation biology because many of them constitute the breeding sites of native aquatic birds, including some endangered species such as the Hooded Grebe (Macá Tobiano), an endemic bird of Patagonia.

Although previous papers on the algal diversity of lakes from this region have revealed a high percentage of wordwide distributed species, some exclusive taxa of Patagonia (probably endemic) were reported as well (TeLL et al. 2011). In the present paper some quite remarkable desmid species, thus far unknown for the Patagonian region, are described.

\section{Material ANd Methods}

Study Area. Strobel Lake Plateau and Buenos Aires Lake Plateau are located in the northwestern part of Santa Cruz Province, in the Patagonian steppe. It is one of the more arid areas of Argentina, receiving about $300 \mathrm{~mm}$ of precipitation per year (CABRERA 1976). Up to $900 \mathrm{~m}$ a.s.l., the dominant landscape is steppe with few gramineous plant species and lichens, rocks being just recorded at higher altitude (IMBERTI 2005). Climatic conditions of the Patagonian steppe are extreme, with large contrast between the seasons. From early autumn to late spring all water bodies remain frozen. The region is characterized by strong winds which generate a continuous mixing of water layers (LANCELOTTI 2009). Some shallow lakes are colonized by aquatic macrophytes, dominated by Myriophyllum quitense KUNTH (LANCELOTTI 2009).

From a geological point of view, the Patagonian Plateau consists of a bed of alkaline basalt caused by tectonic activity during the Tertiary and Quaternary (PANZA \& FRANCHI 2002). On the top of this, natural depressions are distributed that collect water from the snow during winter and from rain during the rest of the year (PEREYRA et al. 2002). In general, the lakes thus formed are shallow $(<5 \mathrm{~m}$ of maximum depth) and range from mesotrophic to eutrophic (IzAGUIRRE et al. 2016). The lakes figuring in the present paper as find sites of the desmid species discussed are located in two dif- 
ferent zones: Strobel Plateau and Buenos Aires Plateau (Fig. 1, Table 1).

For an impression of the general appearance of the lakes mentioned we provide a picture of Lake Chapu, find site of all three desmid species discussed, showing the desolate appearance of the landscape in question (Fig. 2).

Sampling and analyses. Samples were collected in March 2015 from the euphotic zone of the lakes, about $30 \mathrm{~cm}$ below the surface. Water temperature, $\mathrm{pH}$ and conductivity were measured in situ at a depth of $30 \mathrm{~cm}$ with a Horiba D-54 meter (Horiba, Kyoto, Japan).

Phytoplankton samples for quantitative analysis were taken by collecting water in plastic bottles $(0.5 \mathrm{~L})$. After fixation with $1 \%$ acidified Lugol's iodine solution, sedimented cells were counted according to UTERMÖHL (1958) using an Olympus CKX41 inverted microscope at $\times 400$ magnification and sedimentation chambers of $10 \mathrm{ml}$. Samples for qualitative analysis were taken by means of a plankton net, mesh size $15 \mu \mathrm{m}$

\section{RESULTS}

One of the species to be dealt with below, i.e. Cosmarium decussare, was encountered in the framework of a large-scale plankton research programme (IzAGUIRRE et al. 2016). Lakes where this species was found are characterized by $\mathrm{pH}$ values between 8 and 9 , and conductivity values generally ranging from 100 to 500 $\mu \mathrm{S} . \mathrm{cm}^{-1}$ so may be marked as alkaline and mesotrophic (Table 1). The very much higher conductivity in Lake Honda (Table 1) is caused by a high concentration of calcium (bi)carbonate rendering it a pronounced hard water lake. C. decussare occurred in substantial cell numbers (counted according to UTERMÖHL 1958) in the open water column. By far the highest number, i.e., 157 cells per milliliter, was assessed in Lake Chapu (Table 1). As the occurrence of this rare species might predict the presence of other interesting desmid species, from this lake also a plankton net sample towed through submerged vegetation was analysed. In that sample, next to $C$. decussare, two other remarkable desmid species were recorded which, as far as could be traced, are new to science.

\section{Taxonomic account}

Cosmarium decussare Brook et Williamson (Figs 3-5, 10-11)

Nomenclatural type: Brook \& WilLiamson (1983), fig. 7A upper right.

Cosmarium decussare was described by BROOK \& Williamson (1983) from Signy Island in Antarctica. As its description is formally invalid by want of a nomenclatural type (McNeILl et al. 2012, art. 40) we herewith validate the name in question by indicating one of the authors' pictures as holotype.

C. decussare is a remarkable desmid, not resembling any other species. It is characterized by cells that are distinctly twisted at the isthmus whereas the semicells in apical view are curved in a sigmoid way. The latter phenomenon, described by TeILING (1957) as semiradial asymmetry, in genus Cosmarium is most uncommon. Apart from their highly asymmetric shape, cells of $C$. decussare are also very characteristic in

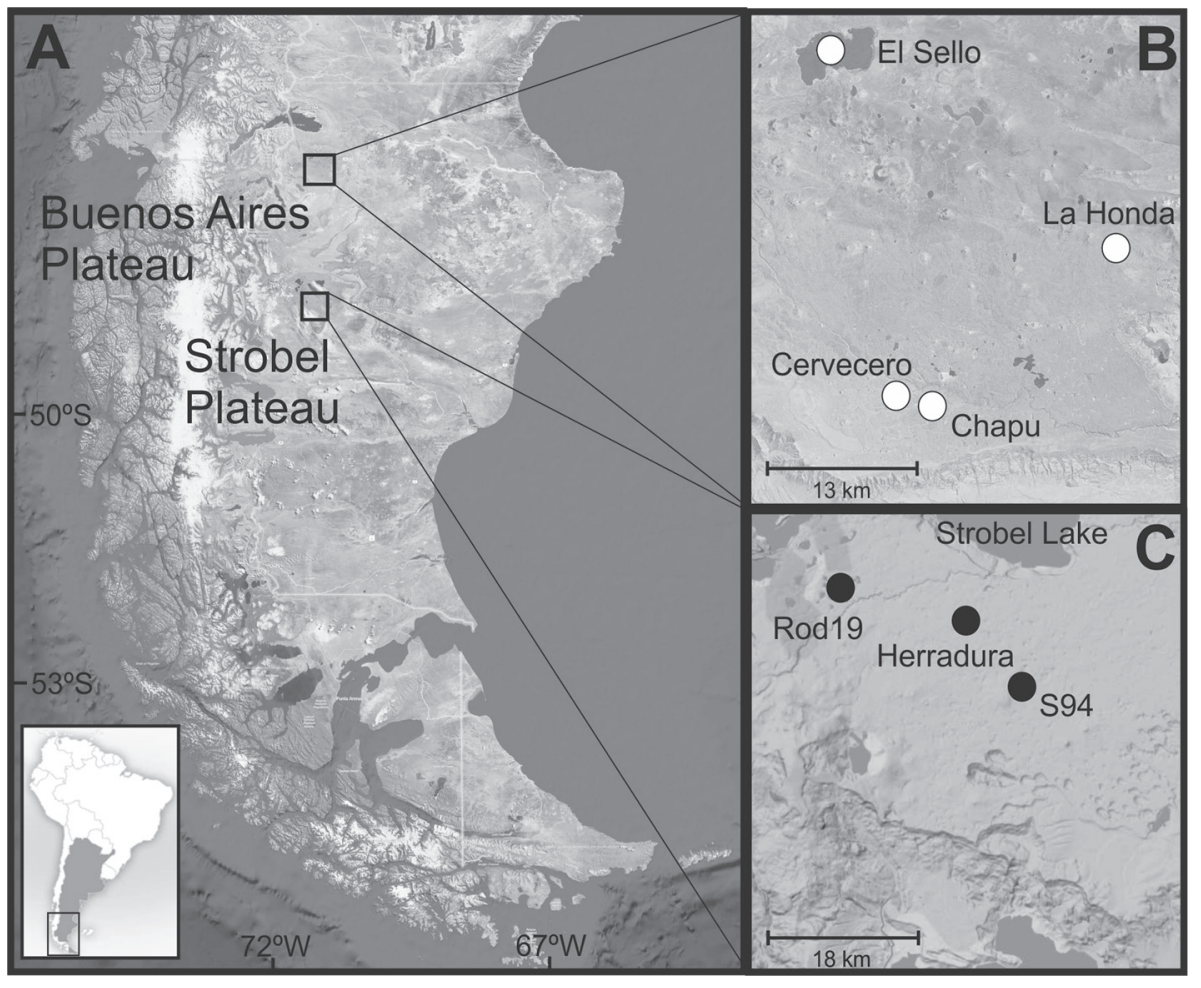

Fig. 1. (A) Strobel Plateau and Buenos Aires Plateau in the northwest of Santa Cruz Province (Argentine Patagonia), (B) shallow lakes in Buenos Aires Plateau: El Sello, La Honda, Cervecero and Chapu, (C) shallow lakes in Strobel Plateau: Rod19, Herradura and S94. Map data 2015 Google. 
outline. Semicell apices are deeply concave whereas the apical and basal angles as a rule are furnished with a short, bar-like process. This feature, in combination with a verrucose cell wall reminds of species from the so-called Euastrum mononcylum group (COESEL 2000) rather than representatives of the genus Cosmarium. However, one of the typical features of the genus Euastrum, i.e., a central inflation of the semicell body is completely wanting. For that matter, molecular studies have shown representatives of the above-mentioned Euastrum mononcylum group such as Eu. verrucosum Ralfs, Eu. germanicum (SChMidLE) Willi Krieg. and Eu. substellatum NoRDSTEDT to be closer related to many Cosmarium species than to 'typical' traditional Euastrum species such as Eu. oblongum RALFs, Eu. binale Ralfs and Eu. bidentatum NäGELI (Gontcharov \& MeLKonian 2008).

The above-mentioned bar-like processes are rather exceptional in desmid morphology as well. A species found to have somewhat similar processes is Xanthidium groenlandicum BoldT (1888). Up to now, that latter species is only known from Greenland (BoldT 1888; LaRsen 1907; NygaARd 1977), remarkably enough, like southern Patagonia a region characterized by a little hospitable climate. For that matter, whereas the processes in Xanthidium groenlandicum are truncate at the top and described to be tubular (so hollow), those in Cosmarium decussare are rounded at the top and give the impression to be solid.

The Patagonian material of $C$. decussare fully agrees with that described by Brook \& WilLiamson (1983) from Antarctica except that our cells are slightly larger, i.e., $\mathrm{L}=35-37 \mu \mathrm{m}$ versus $29.5-32.3 \mu \mathrm{m}$; $\mathrm{B}=$ $34-40 \mu \mathrm{m}$ versus $30.8-31.5 \mu \mathrm{m}$. Also there is a small difference in cell wall ornamentation at the margin of the apical and basal lobes. Whereas our cell material is primarily marked by distinctly bar-like processes at the apical and basal angles, only incidentally concomitant with one or a few accessory nodules at the basal angles (Fig. 5), cells from the Antarctic material show a more uniform arrangement of exclusively small nodules at the angles.

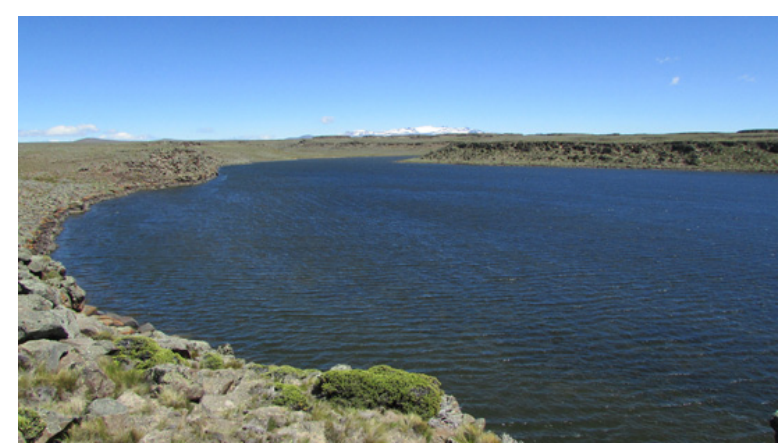

Fig. 2. Lake Chapu situated in Buenos Aires Plateau at an altitude of $1193 \mathrm{~m}$ a.s.1.
After the original description by BrooK \& Williamson (1983) C. decussare was no longer recorded. Earlier papers dealing with desmids from the southern Patagonian region (e.g., Borge 1901; THOMASSON 1957) do not provide any algal pictures resembling this species, nor is the case in a later paper by WiLliamson (2004) from southern Chile. It is striking, therefore, that this species appears to be widely distributed in the Argentine province of Santa Cruz where it was found in some seven lakes located on different plateaux (Fig. 1). Perhaps it has to do with the isolated position and the poor accessibility of those lakes hindering dispersal. The lakes in question, judging from their chemical and biological characteristics (Table 1), may be characterized as alkaline, mesotrophic.

\section{Cosmarium chapuense COESEL sp. nov. (Figs 6-7, 12-17)}

Diagnosis: Cells biradiate, in frontal view slightly broader than long with a deep median constriction. Sinus distinctly open at its apex and the exterior, closed half-way. Semicells 3-lobed, the lateral lobes much more pronounced than the apical lobe. All lobes with a (semi)circular outline. Semicells in apical view tripartite: the central body elliptic-rhomboid, the smaller lateral bodies about triangular, positioned with their base at the mid of the central body. Semicells in lateral view with a widely obcuneate outline and a smaller, about pentagonal body within it. Cell wall for the most part beset with granules arranged in concentric circles around the angles. Chloroplast with two pyrenoids. Cell dimensions: length $62-67 \mu \mathrm{m}$, breadth $73-77 \mu \mathrm{m}$, thickness 53-56 $\mu \mathrm{m}$, isthmus $20-25 \mu \mathrm{m}$.

Holotype: fixed natural plankton sample Hugo de Vries Lab 2016.01 deposited in L (Hic designatus), Naturalis, Leiden, The Netherlands. Fig. 6 represents the holotype.

Type locality: Lake Chapu, southern Argentinian Patagonia $\left(47^{\circ} 9^{\prime} 31.5^{\prime \prime} \mathrm{S}, 71^{\circ} 13^{\prime} 39.9^{\prime \prime} \mathrm{W}\right)$

Etymology: the new species is named after Lake Chapu, the type locality in Patagonia.

Taxonomy: At first sight, when seen in frontal view, cells of $C$. chapuense are slightly reminiscent of some other 3-lobed Cosmarium species, such as C. lagoense NoRDSTEDT or $C$. commissurale RALFS, especially its var. crassum NORDSTEDT. However, apart from much larger dimensions, cells of $C$. chapuense are characterized by a most particular shape in apical and lateral view. The apical view shows two pyramidal wings sharply separated from a central body that is about lined as a rugby ball (Fig. 6). In lateral view cells have the outline of an hourglass (Fig. 6). All in all, this cell shape is unique in the genus Cosmarium rendering it a most characteristic species, not to be confused with any other taxon. 
Table 1. Geographic location and some main environmental variables of the lakes where Cosmarium decussare was found including an indication of the abundance of that species.

\begin{tabular}{|c|c|c|c|c|c|c|c|}
\hline & \multicolumn{3}{|c|}{ Strobel plateau } & \multicolumn{4}{|c|}{ Buenos Aires Plateau } \\
\hline & S94 & Herradura & Rod 19 & Cervecero & Chapu & EI Sello & La Honda \\
\hline Date & $14 / 12 / 2011$ & $25 / 3 / 2015$ & $27 / 3 / 2015$ & $29 / 3 / 2015$ & $29 / 3 / 2015$ & $30 / 3 / 2015$ & $30 / 3 / 2015$ \\
\hline Latitude & $48^{\circ} 35^{\prime} 36.1^{\prime \prime}$ & $48^{\circ} 30^{\prime} 55.5^{\prime \prime}$ & $48^{\circ} 30^{\prime} 0.9^{\prime \prime}$ & $47^{\circ} 09^{\prime} 21.5^{\prime \prime}$ & $47^{\circ} 9^{\prime} 31.5^{\prime \prime}$ & $46^{\circ} 55^{\prime} 9.8^{\prime \prime}$ & $47^{\circ} 3^{\prime} 10.7^{\prime \prime}$ \\
\hline Longitude & $71^{\circ} 14^{\prime} 8.0^{\prime \prime}$ & $71^{\circ} 13^{\prime} 50.0^{\prime \prime}$ & $71^{\circ} 26^{\prime} 7.8^{\prime \prime}$ & $71^{\circ} 16^{\prime} 32.7^{\prime \prime}$ & $71^{\circ} 13^{\prime} 39.9^{\prime \prime}$ & $71^{\circ} 20^{\prime} 15.0^{\prime \prime}$ & $71^{\circ} 3^{\prime} 2.9^{\prime \prime}$ \\
\hline Altitude (m a.s.l.) & 916 & 1036 & 1101 & 1037 & 1193 & 1472 & 1226 \\
\hline Area $\left(\mathbf{k m}^{2}\right)$ & 0.14 & 0.18 & 0.15 & 0.12 & 0.18 & 17.23 & 0.40 \\
\hline Temperature $\left({ }^{\circ} \mathrm{C}\right)$ & 18.1 & 8.1 & 7.0 & 6.4 & 8.0 & 4.6 & 10.7 \\
\hline pH & 8.8 & 8.1 & 8.4 & 8.0 & 8.4 & 8.9 & 8.8 \\
\hline Conductivity $\left(\mu \mathrm{S} . \mathrm{cm}^{-1}\right)$ & 480 & 330 & 390 & 92 & 320 & 126 & 14740 \\
\hline C. decussare (cells.ml-1) & 13 & 15 & 26 & 11 & 157 & 39 & 5 \\
\hline
\end{tabular}

Cosmarium mickeyoides Coesel sp. nov. (Figs 8-9, 16-20)

Diagnosis: Cells biradiate, in frontal view longer than broad, rather deeply constricted. Sinus widely open from an obtuse-angled apex. Semicells about triangular, the apical angles produced to form ear-like, subcircular lobes. Semicells in apical view tripartite: the central body elliptic-rhomboid, the smaller lateral bodies elliptic-pentagonal, positioned at the mid of the central body. Central body of the semicell in lateral view about pentagonal. Cell wall for the most part beset with granules arranged in concentric circles around the angles. Chloroplast with two pyrenoids. Cell dimensions: length $81-100 \mu \mathrm{m}$. breadth $69-80 \mu \mathrm{m}$, thickness $45-52$ $\mu \mathrm{m}$, isthmus $27-29 \mu \mathrm{m}$.

Holotype: fixed natural plankton sample Hugo de Vries Lab 2016.01 deposited in L (Hic designatus), Naturalis, Leiden, The Netherlands. Fig. 8 represents the holotype.

Type locality: Lake Chapu, southern Argentinian Patagonia (479'31.5" S, 71¹3'39.9" W)

Etymology: the new species reminds the Walt Disney cartoon character of Mickey Mouse, because of its characteristic, ear-like apical lobes.

Taxonomy: Cosmarium mickeyoides is a most unusual, large-sized desmid. Actually, its shape is so unknown in the family of the Desmidiaceae that one could think of a new, separate genus. However, in apical view, cells show a striking resemblance with those of the above newly described Cosmarium chapuense, i.e., tripartite semicells consisting of an elliptic-rhomboid central body separated by deep constrictions from the two lateral bodies (Fig. 8). Therefore, pending any possible molecular analyses, as yet we prefer to account it the genus Cosmarium.

\section{Discussion}

In most of the lakes dealt with in the present paper phytoplankton abundance was dominated by chlorococcalean and volvocalean green algae (IzAGUIRRE \& SAAD 2014). In general, desmids were relatively less abundant in terms of density, except in La Herradura where a Closterium species was subdominant in the phytoplankton community. In Lake Chapu, where next to euplankton also tychoplankton was searched for desmids, only three desmid genera were encountered. Next to a number of Cosmarium species, a few representatives of the genus Closterium and a single Staurastrum species were found. Such a low desmid diversity with an emphasis on Cosmarium species is characteristic of circumpolar regions (CoEsEl 1996; Coesel \& KRIENITZ 2008) but also the alkaline nature of the lakes in this part of Patagonia will contribute to this low diversity as most desmid taxa are confined to acidic water bodies (BROOK 1981). WILLIAMSON (2004), who examined samples from some oligotrophic ponds in the southern Chilean Andes, records a distinctly higher desmid diversity (12 genera) than we found in our steppe lakes. So, obviously, it is the combination of a cold climate and alkaline, meso-eutrophic conditions that leads to the scarcity of desmid species in our study area. In view of this low diversity, the occurrence of some remarkable, little-known or even newly reported species is most striking. Cosmarium decussare, thus far only known from an Antarctic island appears to occur in quite a series of the plateau lakes investigated. Also the large-sized species Cosmarium chapuense and Cosmarium mickeyoides, newly described from Lake Chapu, presumably will turn out to be wider distributed when their occurrence will be checked in tychoplankton and benthos samples of other southern Patagonian lakes. With the description of the above-mentioned species 


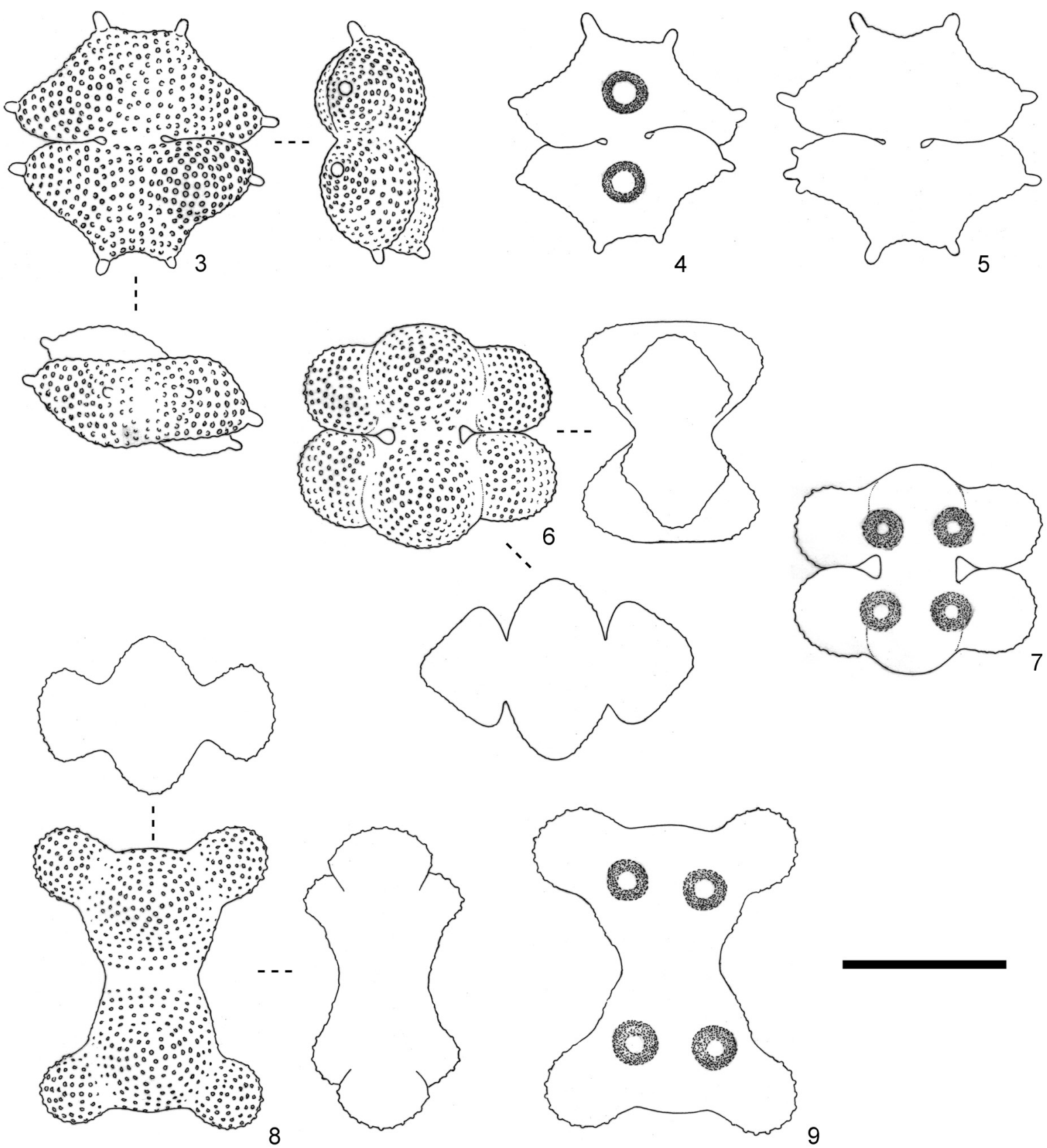

Figs 3-9. (3-5) Cosmarium decussare; (6-7) C. chapuense sp. nov.; (8-9) C. mickeyoides sp. nov. Scale bar $25 \mu \mathrm{m}(3-5), 50 \mu \mathrm{m}(6-9)$.

the low number of desmid taxa endemic of the extratropical part of South America is substantially increased, supporting the thought of a separate biogeographical region within this continent (COESEL 1996).

\section{ACKNOWLedgements}

This study was financed by the following Grants: FONCYT PICT 32732 and FONCYT PICT 2013-0794 of the Argentinean Agency for Scientific and Technogical Investigation; PIP 418, CONICET of the National Council of Scientific and Technical Research of Argentina. We thank Juan Francisco Saad, Julio Lancelotti, Inés O'Farrell and Cristina Marinone for the cooperation in the field work, and the logistic support of the Biological Station of the Parque Nacional Patagonia (Buenos Aires plateau, Santa Cruz Province).

\section{REFERENCES}

BoldT, R. (1988): Studier öfver sötvattensalger och deras utbredning. II. Desmidieer från Grönland. - Bih. Kongl. Svenska Vetensk.-Akad. Handl., Afd. III, 13: $1-48$.

Borge, O. (1901): Süsswasseralgen aus Süd-Patagonien. Bih. Kongl. Svenska Vetensk.-Akad. Handl., Afd. III, 27: 1-40.

Brook, A.J. (1981): The Biology of desmids. - 276 pp., Blackwell Scientific Publications, Oxford.

Brook, A.J. \& Williamson, D.B. (1983): Desmids from some lakes on Signy Island, South Orkney Islands, Antarctica. - Br. Antarct. Surv. Bull. 61: 59-70.

Cabrera, A.L. (1976): Regiones fitogeográficas argentinas. 


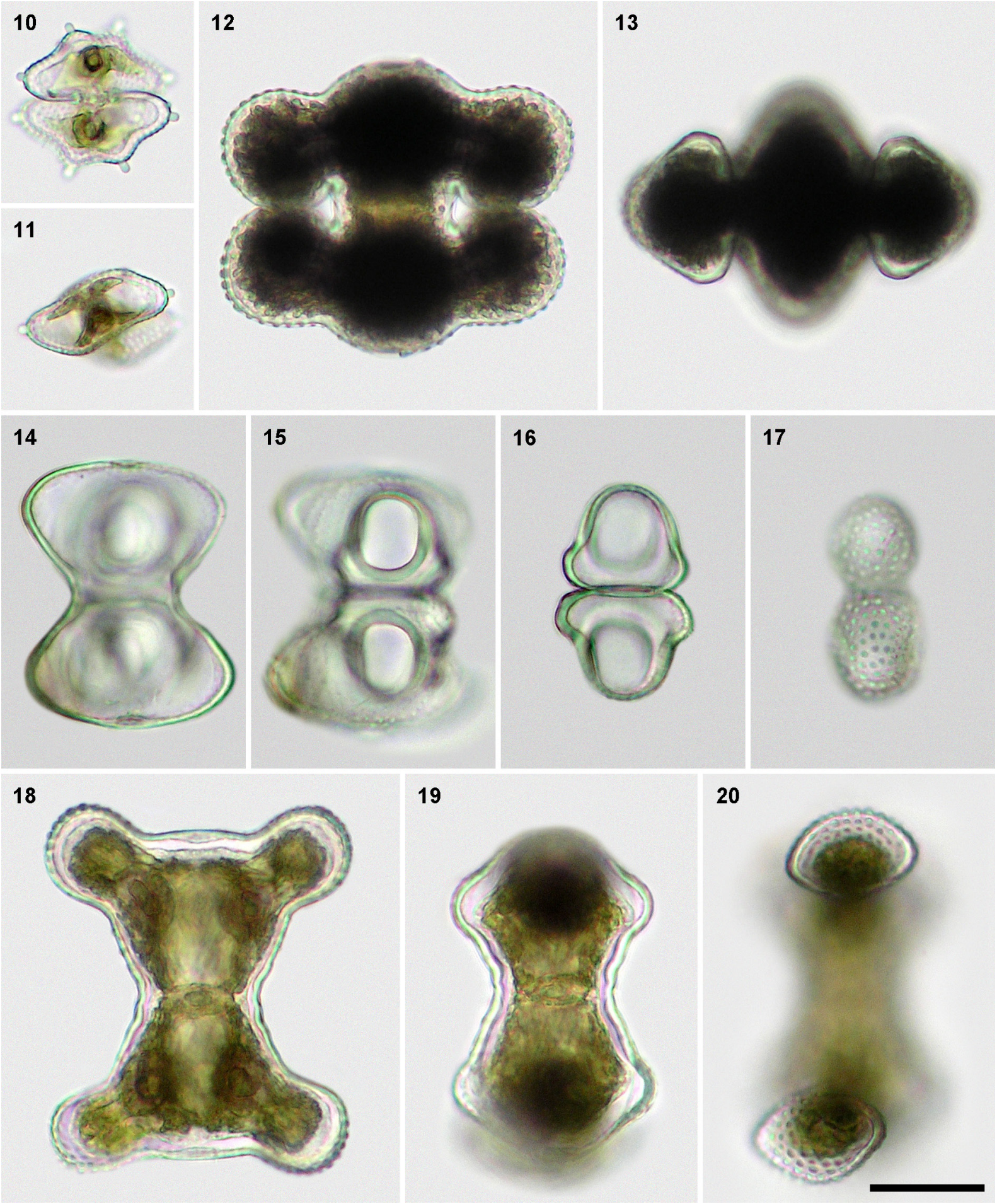

Figs 10-20. (10-11) Cosmarium decussare in frontal view and apical view, respectively; (12-13) C. chapuense in frontal and apical view, respectively; (14-17) C. chapuense, focus-through picture of a cell in lateral view; (18) C. mickeyoides in frontal view; (19-20) C. mickeyoides, focus-through picture of a cell in lateral view. Scale bar $25 \mu \mathrm{m}$.

In: Kugler, W.F. (ed.): Enciclopedia Argentina de Agricultura y Jardinería. Tomo II, Fasc. I. - 85 pp., ACME, Buenos Aires.

Coesel, P.F.M. (1996): Biogeography of desmids. - Hydrobiologia 336: 41-53. http://dx.doi.org/10.1007/ bf00010818

Coesel, P.F.M. (2000): Diversification of the Euastrum mononcylum group of desmids (Chlorophyta, Des- midiaceae). - Syst. Geogr. Pl. 70: 263-273. http:// dx.doi.org/10.2307/3668645

Coesel, P.F.M. \& Krienitz, L. (2008): Diversity and geographic distribution of desmids and other coccoid green algae. - Biodivers. Conserv. 17: 381-392. http://dx.doi.org/10.1007/s10531-007-9256-5

Gontcharov, A.A. \& Melkonian, M. (2008): In search of monophyletic taxa in the family Desmidiaceae (Zyg- 
nematophyceae, Viridiplantae): the genus Cosmarium. - Amer. J. Bot. 95: 1079-1095. http://dx.doi. org/10.3732/ajb.0800046

Imberti, S. (2005): Meseta Lago Buenos Aires. In: Di GiAсомо A.S. (ed.): Áreas importantes para la conservación de las aves en la Argentina. Sitios prioritarios para la conservación de la biodiversidad. - pp. 420 422, Aves Argentinas, Asociación Ornitológica del Plata, Buenos Aires.

IZAGUIRRE, I. \& SAAD, J.F. (2014). Phytoplankton from natural water bodies of the Patagonian Plateau. - In: TelL, G.; Izaguirre, I. \& O'FArRell, I. (eds): Freshwater Phytoplankton of Argentina. - Adv. Limnol. 65: 309-319.

Izaguirre, I.; SAad, J.F.; Schiaffino, M.R.; Vinocur, A.; Tell, G.; SÁnchez, M.L.; Allende, L. \& Sinistro, R. (2016): Drivers of phytoplankton diversity in Patagonian and Antarctic lakes across a latitudinal gradient $(2150 \mathrm{~km})$ : the importance of spatial and environmental factors. - Hydrobiologia 764: 157-170. http://dx.doi.org/10.1007/s10750-015-2269-2

Lancelotti, J.L. (2009): Caracterización limnológica de lagunas de la Provincia de Santa Cruz y efectos de la introducción de Trucha Arco iris (Oncorhynchus mykiss) sobre las comunidades receptoras. - 178 pp., Doctoral thesis, Universidad Nacional del Comahue, Río Negro, Argentina.

LARSEN, E. (1907): Ferskvandsalger fra Vest-Grønland. Meddel. Grønland 33: 305-364.

McNeill, J. et al. (2012): International Code of Nomenclature for algae, fungi, and plants (Melbourne Code), adopted by the Eighteenth International Botanical Congress Melbourne, Australia, July 2011. - 232 pp.,
Regnum Vegetabile 154, Koeltz Scientific Books, Koenigstein.

NygaARD, G. (1977): New or interesting plankton algae. Kongel. Danske Vidensk. Selskab, Biol. Skrifter 21: $1-107$.

Panza, J.L. \& Franchi, M.R. (2002): Magmatismo Basáltico Cenozoico Extrandino. - In: Haller M.J. (ed.): Geología y Recursos Naturales de Santa Cruz. - pp. 201-236, Relatorio del XV Congreso Geológico Argentino, El Calafate.

Pereyra, F. Fauqué, L. \& González Díaz, E.F. (2002): Geomorfología. In: HALLER M.J. (ed.): Geología y Recursos Naturales de Santa Cruz. - pp. 325-352, Relatorio del XV Congreso Geológico Argentino, El Calafate.

TeILING, E. (1957): Morphological investigations of asymmetry in desmids. - Bot. Not. 111: 49-82.

Tell, G.; Izaguirre, I. \& Allende, L. (2011): Diversity and geographic distribution of Chlorococcales (Chlorophyceae) in contrasting lakes along a latitudinal transect in Argentinean Patagonia. - Biodivers. Conserv. 20: 703-727. http://dx.doi.org/10.1007/ s10531-010-9955-1

Thomasson, K, (1957): Studies on South American freshwater plankton. 1. Notes on the plankton from Tierra del Fuego and Valdivia. - Ann. Soc. Nat. Univ. Tartu, S.N. 1: 52-64.

UTERMÖHL, H. (1958) Zur Vervollkommnung der quantitativen Phytoplankton-Methodik. - Mitt. Internat. Verein. Limnol. 9: 1-38.

Williamson, D.B. (2004) Some desmids from southern Chile. - Algological Studies 112: 105-121.

\footnotetext{
C) Czech Phycological Society (2016)

Received May 4, 2016

Accepted June 28, 2016
} 